\title{
Reflexões sobre a pintura
}

Adão Roberto G. Swatowski

Não existe arte sem o olhar do outro

Todos temos, conscientemente ou não, nosso pedaço artista ancorado em algum canto de nossas almas. É dar uma chance e tem início uma viagem fabulosa.

Meu interesse pela arte veio tardiamente. Na profissão que exercia como tripulante de empresa aérea, viajei por países onde ela, a arte, é muito valorizada. Nessas viagens, passei a ter contato pessoal com o que até então só vira em livros e filmes. Isso abriu uma janela para um novo e cativante universo. Ao aposentar-me, orientado pela filha, me inscrevi e prestei vestibular. Cursei Artes Plásticas, na UDESC, onde colei grau em 2011.

Não foi como imaginava. "A academia não forma artistas, ela tem a missão de fazer o artista refletir sobre seu processo", disse-nos um professor logo ao início do curso. Um baque. Vindo de um ambiente estritamente técnico, foi inevitável a mudança de referências, o que naturalmente passou a refletir em minha visão pessoal de mundo. Posso dizer que foi um período conturbado. Toda formação visual anterior fora em cima do desenho técnico, onde o rigor da linha reta era preponderante. Para artes plásticas isso seria um engessamento.

Passado um tempo e ao final, quando acomodadas as junções das vivências, anteriores e presentes, fundidos no cadinho da prática nos ateliês do CEART, o concretismo 


\section{Revista
APOTHEKE}

viria determinar o processo a desenvolver. A linha reta definiu aquele andar, e minha experimentação se escoou na forma geométrica e nos campos de cor. Contudo, após alguma experiência, considero hoje que as mesmas são em si suficientemente poderosas. Sozinhas se realizam no campo pictórico substituindo um mundo externo pela paisagem interior. Ao final, penso que não escolhi o processo, ele me escolheu.

Temos aprendido que, hoje, passados os períodos das vanguardas, não existem mais regras para avaliar ou realizar arte. Cada produção passou a ser compreendida pelo indivíduo de forma pessoal, com emoção e sentidos próprios.

o que tenho realizado, abstração geométrica, acomodase no conceito de arte concreta. Porém, não exatamente aquele conceito, aquela ideia rígida, elaborada em cálculos precisos, sem emoção. Com uma pitada de intuição, coloco a liberdade criativa em movimento, tornando o ato de pintar um campo de experimentação. Há uma racionalidade nas formas, nas grades que dão suporte, nas superfícies homogeneamente pintadas e na orquestração das cores, porém, deixo sempre uma janela para a luz da imaginação.

Lidar com a cor é prazer. Quando da execução de uma tela, existe sempre uma intenção inicial, um projeto, que no decorrer do processo, sempre se altera. O tipo de material empregado e a qualidade da feitura manifestam presença a ponto de dizer que em dado momento a produção tem vontade própria e passamos a dialogar com ela na busca da harmonia desejada. É como o arqueiro que dispara sua seta em direção ao alvo, mas colhe os resultados só quando o alvo é atingido. Na trajetória, os componentes do meio podem mudar, influir e reencaminhar o resultado. Isso torna - ato de pintar uma aventura criativa do seu eu, no seu mundo. Um diálogo do processo com o artista. Pintar exige 


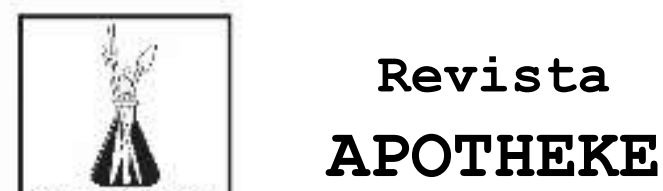

tempo, um tempo de relacionamento com o trabalho. Pintar é tempo. O tempo está na obra. Pode-se dizer também que ela retém memória. Tempo é memória.

Historicamente, os trabalhos estão referenciados no construtivismo, início do século passado. Mondrian, Torres Garcia, Kandinsky, assim como Josef Alberts e Goethe para as cores. Para os construtivistas, a imagem devia ser depurada até seus fundamentos geométricos.

Com frequência, comparo um quadro acabado a uma peça musical. A semelhança é tão próxima quanto subjetiva. O que não é mais abstrato que uma nota musical. Em ambos, há um fundo na música, o ritmo marcado por percussão ou frequências baixas que na pintura pode ser o céu de uma paisagem romântica ou o escuro de um quadro Barroco. Seguese uma melodia de acompanhamento, a rítmica compõe o fundo, que na pintura pode ser o ambiente onde se desenvolve uma cena ou o que se entende como figura secundária. Sobre elas, o solo define e dá clara a mensagem, como numa pintura seus personagens ou joias de um retrato. Todas notas são emitidas nem mais baixo nem mais alto, de forma que o conjunto soe em harmonia não havendo competição entre elas nas cores ou nas notas.

Assim, vejo uma pintura com uma orquestração harmoniosa de cores e formas, capaz de gerar emoções e sentimentos da mesma maneira que uma bela canção.

Cézanne, conhecido por tentar ver geometria em todas as formas dizia que "Pintar não é copiar servilmente e sim captar uma harmonia entre as muitas relações possíveis".

Adão Roberto G. Swatowiski Florianópolis, 19/03/2015 